\title{
The impacts of knowledge of the past on preferences for future landscape change
}

Nick Hanley

Richard Ready

Sergio Colombo

Fiona Watson

Mairi Stewart

E. Ariel Bergmann

Stirling Economics Discussion Paper 2008-05

April 2008

Online at http://www.economics.stir.ac.uk 


\section{The impacts of knowledge of the past on preferences for future landscape change.}

Nick Hanley $^{1 *}$, Richard Ready ${ }^{2}$, Sergio Colombo $^{3}$, Fiona Watson ${ }^{4}$, Mairi Stewart ${ }^{5}$ and E. Ariel Bergmann ${ }^{1}$,

1 Economics Department, University of Stirling, Scotland

2. Department of Agricultural Economics and Rural Sociology, Pennsylvania State University, USA.

3. Department of Agricultural Economics, IFAPA, Granada, Spain

4. Department of History, University of Dundee, Scotland.

5. Centre for History, University of the Highlands and Islands, Scotland

*Corresponding author. Contact: Nick Hanley, Economics Department, University of Stirling, Stirling FK9 4LA, Scotland, UK. Email n.d.hanley@stir.ac.uk. Telephone +44 (0)1786 466410 Fax +44 (0) 1786467469.

We thank the AHRC for funding this work, and Carys Swanwick for very helpful advice on the broader literature on landscape perceptions. We also thank three referees for helpful comments on a previous version.

JEM codes: Q2, N5, H4

Keywords: environmental history; landscape change; national parks; landscape preferences; woodland management.

\section{April 2008}




\section{Abstract}

In this paper, we investigate whether people's knowledge of the past influences their preferences and values towards future landscape change. "Knowledge of the past” is one aspect of the information set held by individuals, and a well-established finding in economics is that changes in information can change preferences and values. The particular aspects of knowledge of the past we work with here are (i) awareness of past landuse, as represented by woodland cover and (ii) awareness of differing and sometimes contradictory literary impressions of this past landscape. The case studies used here relate to prospective changes in woodland cover in two UK national parks, the Lake District and the Trossachs. We find that people who are made aware that the landscape has changed over time, or that perceptions of the landscape have changed over time, are more likely to favour changes to the current landscape (are less likely to favour the status quo). Knowledge of the past therefore seems to have an impact on preferences for future

landscapes. We also investigate the impacts on preferences of how "special”, how "wild” and how "worked in" people perceive the landscapes of these two national parks to be. 


\section{Introduction}

In economics, what people know about an environmental good can be expected to partly determine their preferences over possible changes in the quality or quantity of this good, and the economic value they place on a particular change in quantity or quality. This has been argued to be the case theoretically, and shown to be true empirically, in a great number of stated preference studies for environmental goods such as wildlife and habitat conservation (see, for example, the review in Munro and Hanley, 1999). Information can impact on stated Willingness to Pay (WTP) either in terms of the impacts of new information on beliefs, or through an increase in the salience of an aspect of the respondent's existing information set. A change in information sets, whether new or changed in salience, can then impact on WTP through its impacts on preferences (Fischer, 2003).

This paper considers the effects on preferences for future landscape change of information about the past history of landscapes, both in terms of previous patterns of land use, and previous cultural impressions of the area. This seems both useful and relevant, partly since current concepts of what "landscape" means, and the accompanying focus on "landscape character”, incorporate aspects based on past experience. For example, the European Landscape Convention defines landscape as:

"an area, as perceived by people, whose character is the results of the action and interaction of natural and/or human factors. The term 'landscape' is thus defined as a 
zone or area as perceived by local people or visitors, whose visual features and character are the result of the action of natural and/or cultural (that is, human) factors. This definition reflects the idea that landscapes evolved through time, as a result of being acted upon by natural forces and human beings. It also underlines that landscape forms a whole, whose natural and cultural components are taken together, not separately." (Council of Europe, 2000; emphasis added).

How people think about landscape quality may depend on what they believe about past uses of a landscape, how this use has changed over time, and how that landscape has been represented culturally. In this paper, we are interested in the effects of the acquisition of information regarding the landscape history of two national parks in the UK. This is of particular policy interest given questions about what landscapes should be preserved, and whether the current appearance of a landscape is that which we are trying to conserve, or whether some past ideal of the landscape is preferred instead. This leads on to a related question as to whether the current landscape of a national park has some special standing, or whether a past alternative is preferred by people. Our objective in this paper is thus to empirically investigate whether different levels of information about the "history" of a landscape have a statistically-significant effect on preferences for these prospective landscape changes, and on economic measures of the value of future landscape changes, as measured by peoples’ Willingness to Pay (WTP).

In what follows, section 2 sets out some relevant aspects of the large and very diverse literature on preferences towards landscape. This literature spans the fields of economics, 
human geography, landscape studies, rural sociology and environmental psychology, so that the review presented is highly selective. Its purpose is to locate the objectives, methods and findings of this paper within the wider literature. Section 3 describes the case study areas and the design of the stated preference studies, including the nature of the historical information presented. Section 4 presents results, firstly for the effects of information on our measure of preferences (section 4.1) and then on willingness to pay for landscape change (section 4.2), whilst section 5 contains a discussion. Section 6 concludes.

\section{Preferences for landscape.}

What we mean by a "landscape" and by "landscape quality" has been much discussed in the literature (Daniel, 2001). Within economics, landscape is thought of as a physical entity which is valued for its aesthetic attributes. Landscape values are often thought of as public goods, in the sense that they are non-excludable and non-rival in consumption. The market thus fails to place an adequate price (value) on landscape quality, and so nonmarket valuation techniques such as contingent valuation are used to estimate this value, and how landscape values would change when, for instance, land uses change (Garrod and Willis, 1995; Hanley, Wright and Adamowicz, 1998; Gonzalez and Leon, 2003). Preferences for landscape refer to the ranking of alternatives within a set of choices; values refer to people's maximum Willingness to Pay to attain or conserve a particular landscape. The environmental economics literature has spent time both investigating the extent of preference heterogeneity (ie variability in preferences across 
people), and of methods for dealing with it, in the context of environmental values (see Hynes 2008 and references cited therein).

Beyond economics, landscape has been described as the intersection between the physical characteristics of a place and human perceptions and experience of that place. Dramstad et al (2001) suggest that “..people are influenced by a mixture of logic and emotion that incorporates aspects of landscape structure, biodiversity and cultural heritage" . Landscape quality is seen to depend on perspective, in the sense of which approach is taken to assigning qualities, whether based on expert/design approaches, or on public perceptions (Daniel, 2001). Expert ratings of landscape quality would also depend on perspective, for example whether the landscape is conceived mainly in terms of its aesthetic quality, or its ecological quality, though the extent to which these two qualities are interlinked is also an issue. Preferences for alternative landscapes are expressed in terms of which one is liked best from a set of alternatives, or in terms of a strength of preference score across alternatives (Kaltenborn and Bjerke, 2002). Landscape "value" is more likely to be thought of in terms of why a landscape is important to someone, rather than what they are willing to pay to protect it, or their preference for it relative to others.

Cheng et al (2003) note that the concepts of "sense of place", and "place attachment" have been used to characterize the relationship that people have with a landscape. What determines this sense of place for an individual can also be expected to influence how they value a particular landscape, and how they value prospective changes in this landscape. The place attachment literature suggests that three factors matter to sense of 
place: biophysical attributes and processes (the physical environment), social and cultural meanings, and political processes (Cheng et al, 2003). At the extreme, some authors have argued that sense of place is an entirely social construct (Greider and Garkovitch, 1994). However, Stedman (2003) argues that environmental (physical) factors are likely to be of considerable importance in setting limits on and creating opportunities for how land is used and thus perceived, and offers empirical evidence that a variety of physical characteristics of the environment were strongly related to an index of "place satisfaction”.

Since preferences for a particular landscape depend both on the nature of that landscape (for example, how "wild" it is thought to be, and on the person whose preferences are being sought, measures of preference for a given landscape will vary across people [in economic parlance, preferences are heterogeneous]). Such variation is clearly recognised in the literature. For example, Zube et al (1983) and Bullen (1999) refer to "naturalness" as an important feature of landscapes to some people. Variations in preference have been observed between groups who use the landscape in different ways: For example, the “insider/outsider” can matter: Jones et al (2000) asked visitors and residents of Cumberland Gap National Historic Park in Tennessee to rate photographs of the area. Residents felt at ease with the scenes and that they had an atmosphere of friendliness and closeness. Therefore preference ratings were high. These were not reflected in the visitor experience. Gomez-Limon and Fernandez (1999) asked farmers, managers and recreationists about their preferences for different landscapes found within the Iberian Peninsular (Spain). Livestock farmers preferred open landscapes whereas the other users 
liked landscapes with denser vegetation. Similar findings on the differences in attitudes to rural landscapes on the part of producers has been noted by ven den Berg et al (1998). Attitudes have also been found to matter: Ribe (2002) asked groups of people with differing levels of interest in conservation and production about scenic beauty and acceptability using mountain scenes across Oregon and Washington. People with strong environmental value orientations rated "managed" scenes as a lot less acceptable than those people interested in production even if the beauty ratings were similar. Similar findings on the importance of attitudes are noted by Kaltenborn and Bjerke (2002).

The meaning of landscape is clearly thus much more than a physical one, incorporating what people perceive about past, current and future uses of that environment, and their attitudes. For this reason, we might expect changes in people's information sets with regard to past uses or past perceptions of a particular landscape to impact on the value of future changes to that landscape. Some of this variation may be due to differences among people in their knowledge or perceptions of how the landscape has changed over time. Variation is also expected, given the literature above, from how people have experienced the landscape in terms of whether they are local residents or visitors. If land managers seek to create those landscapes that command most public support, then understanding how preferences for landscape vary across people and how they depend on current impressions of the past is important. This is also the case if we wish to apply cost-benefit analysis to possible policy options for national park management. 


\section{Study design ${ }^{1}$}

\subsection{Case study sites}

The study was conducted in two UK national parks, the Lake District National Park, located in North-West England, and Loch Lomond and the Trossachs National Park, located in central Scotland. These areas were chosen as case studies because they have been important tourism destinations for over 200 years and are renowned for the inspirational beauty of their lakes and hills, which has led to them being labelled as "iconic" British landscapes. For more information on and images related to each park, the reader can consult www.lake-district.gov.uk and http://www.lochlomond-trossachs.org/. The areas were designated as national parks in 1951 and 2002 respectively. Both areas were the focus for "Romantic Tourism”, which developed in the UK in the late 18th century, and both were the source of inspiration for such leading Romantic writers and artists as William Wordsworth, Samuel Taylor Coleridge, J. M. W. Turner and Sir Walter Scott. Indeed, these artistic representations of the two areas as "idealised" landscapes might be expected to have echoes in current preferences over landscape change.

Land use in the Lake District National Park is comprised of $48 \%$ of land as grass, heath and moorland, $12 \%$ as woodland, divided roughly equally into conifer and deciduous woodland, $15 \%$ as cultivated land, $4 \%$ as water and $5 \%$ as "other” (LDNPA, 2003). There exists a long history of debate over land use in the Lake District since it became a national park (and indeed before this, as we note below). Writing in the early $19^{\text {th }}$ century, William Wordsworth is credited with initiating concerns for the conservation of the Lakeland landscape, expressing his anxiety over new buildings and a distaste for

\footnotetext{
${ }^{1}$ A copy of all survey materials is available from the corresponding author on request
} 
exotic conifers, especially larch (Whyte, 2002). He also opposed the coming of the railway to Windermere, a campaign that was to continue long after his death and indeed stimulated the founding of local campaign groups, which in the $20^{\text {th }}$ century became embroiled in an attempt to restrict the development of large scale commercial conifer plantations in the heart of the Lake District. Unlike the railway issue, this was a major success for the conservationists, and has effectively restricted coniferous forest plantations in the Lake District (Sheail, 1976). There is thus a long history of people campaigning against change to this particular landscape.

A comparable tradition of opposition to development is not evident for Loch Lomond and the Trossachs ${ }^{2}$, where the landscape has undergone considerable change in the last 150 years, particularly as a result of afforestation and the construction of water supply infrastructure. This is despite the use of the landscape of this area as a Romantic device in the $19^{\text {th }}$ century popular writing of Sir Walter Scott particularly. Large swathes of the Trossachs were purchased by the Forestry Commission in the first half of the $20^{\text {th }}$ century and planted mainly with Sitka spruce, although the hill slopes around Loch Katrine, the picturesque core of the Trossachs, remain open, largely because of its function as the reservoir for the main water supply for the city of Glasgow. Today, 26\% of the Trossachs is covered in woodland and forestry, of which $70 \%$ is conifer plantation, whereas only $12 \%$ of the Lake District is woodland and half of that is broadleaved. Other land uses in the Trossachs are rough grasslands and moorland 50\%, improved agricultural land 15\% and water 3\% (LLTNPA, 2005). In the Trossachs, 70\% of the Park's woodlands are coniferous. Most of this forest is public land, owned and managed by the Forestry

\footnotetext{
2 “The Trossachs”, from now on.
} 
Commission. A national forest park was established in 1953, and was one of the earliest such areas to be created in the UK. It was designed to provide recreational opportunities as well as commercial returns; however, many of the Trossach forests are regarded as poorly designed and restructuring these forests to accommodate landscape and other concerns is currently a major issue for the National Park authority and Forestry Commission. In addition, with the current emphasis on biodiversity conservation and landscape protection in both parks, the restoration and expansion of native broadleaved woodland has also been a major focus for debate and action. In fact, both parks support important areas of native woodland of high conservation value (LLTNPA, 2006; LDNPA, 1995).

\subsection{Information on past landscapes}

We used a questionnaire survey of local residents and visitors in these two national parks to investigate the effects of providing information on past landscapes on preferences towards future landscape change. Two sorts of historical information were included in the design of our questionnaires. The Lake District is an iconic landscape which has featured in traveller's accounts for nearly 300 years. However, the way in which this landscape has been viewed has changed over time. Two very different traveller's accounts were therefore used in the Lake District survey, representing a "positive" and a "negative" impression of this landscape. The positive view was taken from the work of Thomas Pennant, a naturalist, who in 1772 wrote: 
"Reach Coninston or Thurstain Water, a beautiful lake .... The scenery about this lake ... is extremely noble. The east and west sides are bounded by high hills often wooded; but in general composed of grey rock, and coarse vegetation .... At the north western extremity the vast mountains called Coninston Fells form a magnificent mass. ... Reach Graithwaite [Lake Windermere] ... The variety of beautiful bays that indent the shore; the fine wooded risings that bound each side; and the northern termination of lofty fells patched with snow, compose a scene the most picturesque that can be imagined."

The "negative view" was taken from the writing of Daniel Defoe, after his visit to the area exactly fifty years before Pennant, in 1722 :

"Nor were these hills high and formidable only, but they had a kind of an unhospitable terror in them. Here were no rich pleasant valleys between them, as among the Alps; no lead mines and veins of rich oar, as in the Peak; no coal pits, as in the hills about Hallifax, much less gold, as in the Andes, but all barren and wild, of no use or advantage either to man or beast.... Here we entered Westmoreland, a country eminent only for being the wildest, most barren and frightful of any that I have passed over in England, or even in Wales itself...."

The split-sample design adopted was that $25 \%$ of the sample received neither reading, $25 \%$ were shown the negative reading (ie from Defoe), $25 \%$ the positive reading (ie from Pennant), and 25\% were shown both readings. 
In the Trossachs sample, a different historical lens was used, namely information on past landuse and landscape change. Two maps were obtained showing the extent of woodland cover in the study area. The maps were drawn in the 1750s and in 1890, and indicate considerable changes in both the extent and distribution of woodland in the Park relative to current woodland cover. These maps were presented to respondents along with a verbal description of woodland in the area at these two time periods, adapted from contemporary sources. The first map is part of the Military Survey of Scotland (1747-55), or as it is more commonly known, the "Roy Map", and was the product of the first systematic survey of mainland Scotland. While they looked at this map, respondents were told:

"This map shows the Trossachs in the 1750s - the woods are marked as dark green dots. At this time, the valleys consisted of meadows and arable land, along with the woodands you can see on the map. Higher up, on better land, you could find semi-natural woods of oak, birch, pine, hazel, alder, ash, plane, holly, bird cherry and willows. There were also plantations of pines, larch, spruce, elm, beech, lime, walnut, chestnuts, poplars, aspens, laburnums and hollies.”

An Ordinance Survey map was used to show woodland cover in 1890, and respondents were told the following as they looked at this later map:

"In 1843, the "Statistical Account” for Aberfoyle described ... "native woods of oak, ash, birch alder, hazel, bird cherry and willow”, and mentioned that larch had been recently 
introduced. Around Callander, the account described woodlands of oak, ash, alder, Scots Pine, and willow, and mentioned that oak woods were cut every 16 -20 years for their bark, which was sold to tanners. Also described were "rich and extensive plantations of beech, lime and chestnut trees", which were "beautifying the appearance of the countryside”. This Ordinance Survey map comes from slightly later, in the 1890s. You can see the woodlands marked on it clearly."

The split-sample design adopted was that $25 \%$ of the sample received neither map, $25 \%$ were shown the 1750 s map, $25 \%$ the 1890 map, and $25 \%$ were shown both maps.

The literature reviewed in Section 2 suggests that additional factors will help determine preferences for landscape other than information on past impressions of the landscapes and on past land use. Several studies (eg Habron, 1998; Kaltenborn and Bjerke, 2002; Bullen, 1999) present evidence that how "wild" people feel a landscape is affects their assessment of relative preference. We thus included a question asking people to rate how wild they felt the landscape of the Lake District/Trossachs to be, on a scale of 1 (not at all) to 5 (very). The sense of place literature (eg Stedman, 2003) suggests that preferred landscapes can be "special" to people. Respondents were thus asked how special they felt the Lake District/Trossachs to be, from 1 (not at all) to 5 (very special). Finally, several researchers have pointed to the importance of the cultural aspect of landscapes, for example in terms of old buildings significant in terms of past associations (eg Kaltenborn and Bjerke (2002), in the context of "traditional” farmed landscape). Respondents were 
thus asked how long they felt people had "lived and worked in the Lake District / Trossachs”, again on a 5 point scale from 1 (hardly ever) to 5 (always).

\subsection{Measuring Impacts on Preferences and Values}

To investigate the effects of this historical information on preferences and values, we first use a ratings scale to determine which landscape option individuals prefer, and then use the Contingent Valuation method to measure the value to them of this preferred change (Bateman et al, 2002). The landscape change used was prospective changes in future woodland cover in the two national parks. As stated above, woodland and forestry have had very different histories in the two case study areas. The dominance of forestry, especially coniferous plantations, in the Trossachs National Park has resulted in a very different landscape from the one noted by the early tourists. Respondents were told how much woodland cover currently existed in the area, and the nature of this cover, whilst being shown a map indicating current forest areas. For instance, for the Lake District sample, respondents were told that:

"Woodlands and forest cover around one-third of Lake District National Park, and are regarded by some as being important to its special qualities. Currently, it is made up of a mixture of broadleaved woods with species such as oak and ash; and plantations of single evergreen species such as Norway Spruce. Land owners within the park are interested in harvesting the timber, but this would have effects on the landscape. The National Park Authority has to decide how to balance these opposing interests.” 
They were then told that the Park Authority had to decide what strategy to pursue over the next 20 years, and that two broad options existed:

Option 1: If the National Park Authority decides to reduce the forest coverage, this will be carried out by cutting down some of the plantations of evergreens. This would leave about $20 \%$ of the National Park still covered in forest.

Option 2: If the National Park Authority decides to increase the forest coverage, this will happen by planting a mix of mainly broadleaved trees such as oak and ash. These new plantings will bring the total wooded area to about $40 \%$ of the National Park.

Respondents then completed a "strength of preference" score card indicating which of these two scenarios they preferred, or whether they preferred no change to the existing situation (the status quo). This was accomplished using a 9-point scale of numbered boxes. Ticking a box in the range 1-4 indicated a preference for Option 1 above (felling), with lower values implying a stronger preference for felling (respondents were first offered an explanation as to how to complete this question). Ticking a box numbered 6-9 implied a preference for Option 2 (planting), with higher values implying a stronger preference for planting. Ticking Box 5 was equivalent to preferring to keep the current situation or status quo, rather than have either of the two change options. Responses to this question thus yield a measure of preferences towards future landscape change in the relevant park. Note that in what follows, we do not make any assumptions about the ability of the rating scale to measure intensity of preferences: we simply use this scale to 
indicate which option was preferred: felling, status quo or planting. The intensity of preferences are measured using WTP instead.

Dependent on whether an individual preferred Option 1 (reducing forest cover) or Option 2 (increasing forest cover), they were asked their maximum Willingness to Pay to have this option go ahead. Willingness to Pay is a key economic measure of value, and contingent valuation is a widely-used method for estimating such landscape values and was highly suitable in this instance (Bateman et al, 2002). Sampling was split between local residents and tourist visitors; for the former group, the bid vehicle was an increase in local taxes; for the latter, it was an increase in car parking fees in the area (these are implemented by the Park Authority). Reasons why such payments were necessary to secure the option were provided; for instance, for Option 1 the following text was read to respondents who were local residents:

"Once the trees had been felled, the National Park Authority would need money to restore the landscape, for example by removing tree stumps and encouraging wild flowers and plants to re-grow in the felled areas. Given limited government resources, the Park Authority will need extra funds for the felling project. Money dedicated for this purpose would be collected by increasing local council taxes. This increase would last for 10 years. The only way that the felling project (Option 1) could go ahead is if these extra funds were raised." 
Those preferring the status quo were not asked their WTP; instead, along with those refusing to give any positive payment amount for either Options 1 or 2 , they were asked why this was so, in order to distinguish protest bids from genuine zeros (Bateman et al, 2002). The elicitation format used was a payment card showing 4 amounts. Individuals were asked whether they would definitely pay, probably pay, or definitely not pay each amount (the order in which amounts were read out was randomized). This design allows for a degree of uncertainty in how much value respondents place on a given environmental change (Ready et al, 2001). Payment levels were based on a pilot survey in each area of 50 respondents which used an open-ended payment question design.

\subsection{Conduct of Survey}

Sampling was carried out by a market research firm using face-to-face interviews over the period July-August 2005. Tourists were sampled on an intercept basis at popular visitor locations in both national parks. Local residents were selected using random sampling based on the electoral roll. We obtained 502 responses in the Lakes and 504 in the Trossachs, divided equally between tourists and local residents in both cases.

\section{$\underline{\text { 4. Results }}$}

\subsection{Preferences for landscape change}

Figure 1 shows the distribution of preference scores towards future landscape change in the two areas, pooled across all information treatments. As may be seen, in the Lake District sample, a large number of preference votes were for the status quo (212 out of 502 responses). Amongst those preferring a change, more expressed a preference for 
increasing woodland cover than decreasing it, since the number of people giving a score in the 1-4 range (70) was less than the number giving a score in the 6-9 range (220). This means that a greater number of preference votes in total were given to increasing woodland cover than to the status quo. A statistical test shows that visitors and residents do not differ significantly in terms of their preferences for future landscape, in terms of their choices across these three options (felling, planting, status quo).

With regard to the Trossachs sample, a majority of respondents are in favour of an increase in woodland cover, with the highest number of votes going to the strongest expression of preference for this option. An equal number of respondents - 97 - voted in favour of the status quo and a reduction in woodland cover. The status quo was thus a much less popular option in the Trossachs than in the Lakes. In the Trossachs, preferences differ significantly between visitors and residents: residents are more likely to prefer the felling option and visitors are more likely to prefer the planting option. We can reject the null hypothesis that the two groups are independent in their choice between felling and planting (chi-square $=30.20$, prob $=0.00$ ). However, selection of the status quo option is independent from respondents' type.

We also compared sample characteristics between visitors and residents in the two areas (see Table 1). We used the U-Mann Whitney test to compare for differences between ordinal variables (how special is the area, how wild is the landscape, age, income, education level) and the chi-square test to assess for differences between categorical variables (gender and membership of any environmental association). There are 
significant differences in how visitors and residents rated the park features and in some respondents' socio-economic characteristics. In particular, in the Lake District, visitors consider the park more special and wild than residents. In the Trossachs, we have an opposite rating of the question "do you think the park is special", with residents considering the park more special than visitors. Concerning differences in socioeconomic characteristics, in the Lake District the two sub-samples differ in terms of education level; visitors, on average, have a higher level of education than residents. In the Trossachs the two samples differ in gender and age, in the sense that more males and older people were interviewed in the resident sample relative to the visitor sample.

Results on which future landscape respondents preferred were also tested to see whether a measure of familiarity with the landscape was related to preferred landscape change. For visitors, familiarity was proxied by how many trips they had made to the national park where they were interviewed in the previous 12 months. Results showed no statistically significant effect for whether a change away from the status quo was preferred according to the number of previous visits in either the Trossachs or the Lakes. For local residents, familiarity was proxied by how long they had lived in the national park. Again, preferences for a change in landscape were not significantly related to this measure for either park. The conclusion that arises is that familiarity, as measured here, is not related to preferences for landscape change.

\subsection{Impacts of historical information on preferred future landscape}


To investigate whether the historical information treatment affected the proportion of respondents who expressed a preference for felling, planting, or the status quo, a multinomial logit choice model was estimated (Greene, 1993). The estimated model predicts the probability of choosing (expressing a preference for) each of the three options as a function of the landscape history information set given to respondents, whether they were residents or visitors, and their responses to questions as to how wild ("WILD") or how special (SPECIAL) they feel the landscape to be, and how long they feel people have lived and worked in the landscape (WORK). Socio-demographic measures that were not found to be related to choice in either study area were membership in an environmental organization, self-described level of spirituality, education, and gender. These variables were thus omitted from subsequent analysis.

Table 2 shows the parameter estimates for the multinomial logit choice model for the Trossachs sample. For each variable (for example, 'SPECIAL'), two parameters are estimated, one measuring the impact of that variable on the utility from choosing the "planting" option, the second measuring the impact of that variable on the utility from choosing the "felling" option. The third option, the status quo, is treated as the baseline, with utility set equal to zero. To test whether a variable affects choice probabilities, it is therefore necessary to jointly test the statistical significance of both parameters for that variable. The results of such significance tests are shown in the fifth and sixth columns of Table 2. For the Trossachs, the variables WORK and WILD did not significantly impact the choice probabilities, as may be seen. Residents are more likely to choose felling and less likely to choose planting than visitors, with the differences highly 
significant. People who give the area a higher score for SPECIAL are more likely to choose the status quo, and less likely to choose planting or felling.

Of particular interest is the effect that landscape history information treatments had on choices. A joint test of all three information treatments showed that the treatments did impact choice probabilities, and that the differences were statistically significant at the 5\% level. Information effects did not differ between residents and visitors (i.e. a set of interactions between residence and information treatments was not jointly significant).

In order to better understand the direction of the information treatment effects, the probability of choosing each of the three options was calculated from the estimated model for different types of respondents and for different treatments. These are shown in Table 3. Most strikingly, all treatments that involved showing a map of past woodland cover to respondents reduced the probability of the respondent choosing the status quo as the preferred option. This reduction was greatest when the 1890 map was shown alone. This seems to suggest that learning that the landscape has been different in the past reduced peoples' preference for keeping the current landscape. All treatments that included a map of previous woodland cover increased the probability of choosing the planting option. When the 1750 s was shown alone or in combination with the 1890 Map, the probability of choosing felling decreased. However, when the 1890 Map was shown alone, the probability of choosing felling was essentially unchanged. Additional statistical tests showed that the treatment effect of showing the 1890 Map alone was different from the effects of showing either the 1750 Map or showing both maps 
$\left(\chi^{2}(2)=7.49, p<0.05\right)$. Further, the treatment effect of showing the 1750 Map alone was not significantly different from the effect of showing both maps $\left(\chi^{2}(2)=0.24\right)$.

For the Lake District, the choice model parameter estimates are shown in Table 4. In contrast to the Trossachs sample, residents did not show significantly different preference patterns than visitors. The variable WILD was only marginally (with $10 \%$ probability) significantly associated with preferences, and differences in the WILD variable were associated with only small differences in choice probabilities. The variables WORK and SPECIAL were significantly associated with differences in preferences. People with higher scores for WORK - that is, those who felt that people had “..always...lived and worked in the Lake District” - showed a lower probability of choosing the status quo, a lower probability of choosing felling, and higher probability of choosing planting. People with higher SPECIAL scores (ie who felt the Lake District was more special) had a lower probability of choosing the status quo, and a higher probability of choosing the planting option.

Turning to information treatment effects in the Lakes, a joint test failed to reject the null hypothesis that choice probabilities were the same across all treatments. However, even though treatment effects were not found to be statistically significant for the Lake District sample (recall that in this case the "treatment" was whether people were read the positive, negative, neither or both readings), the pattern of treatment effects is similar to that found in the Trossachs sample. Calculated choice probabilities for the Lake District are shown 
in Table 5. As was the case in the Trossachs, provision of extra information is associated with decreases in the probabilities of choosing the status quo and the felling options, and an increase in the probability of choosing the planting option. Again, it seems that being made aware that past impressions of the landscape have been highly variable reduces the demand for the status quo. The changes in choice probabilities were largest when Defoes’ Negative Reading was provided, either alone or in combination with Pennant's Positive Reading. A restricted statistical test of whether the common effect of providing the Negative Reading, either alone or in combination with the Positive Reading, affected choice probabilities relative to the baseline treatment was marginally significant $\left(\chi^{2}(2)=4.75, p<0.10\right)$.

The main conclusion that arises from these results is therefore that any treatment which involves respondents learning that the landscape has changed over time (Trossachs) or has been perceived differently over time (Lake District) produces a reduction in peoples' preferences for the status quo option. In other words, learning that landscape evolves in physical terms and also evolves in terms of how it is perceived, reduces peoples' desire to keep the current landscape as fixed and un-changing. This effect was stronger when the information provided was in the form of historical maps of actual land cover, and weaker (but still suggestive) when the information was provided in the form of readings from popular literature.

\subsection{Willingness to pay for landscape change}


We used a simple spike model (Kristrom, 1997) to estimate Willingness to Pay for an increase or a decrease in woodland cover in the two national parks. A spike model was used since a large proportion of respondents preferred the Status Quo and were therefore assumed to have expressed a zero WTP for either planting or felling. We further assumed that WTP was distributed as a logistic function where the constant and the bid were included linearly (Bateman et al, 2002). Table 6 shows mean WTP for planting and for felling in the two areas when no distinction is made between which information treatment respondents were allocated to, since splitting the samples on this basis would render subsamples too small for meaningful analysis. We show results when responses from residents and visitors are pooled together, and where these groups are separated. As may be seen when pooling across visitors and residents, respondents who preferred planting had higher WTP for this landscape change than did respondents who preferred felling, with the lowest WTP value being attached to the felling proposal in the Lakes. WTP for both management options (felling and planting) was higher in the Trossachs than in the Lake District. Looking at residents and visitors separately, in the Trossachs visitors are WTP less for the felling option than are residents, whilst in the Lakes this pattern is reversed. Notice the large fraction of respondents in the Lakes who prefer felling but have zero WTP for their preferred option (82\% for residents and 78\% for visitors). For planting, visitors in the Trossachs are WTP more than residents, a pattern repeated in the Lakes.

A logical next step in the analysis would be to consider the effects of treatment, in terms of which historical information was provided, on WTP for a respondent's preferred 
option. However, due to the small sub-sample sizes and the imprecision of the WTP estimates, none of these information effects is statistically significant at the $95 \% \operatorname{level}^{3}$. It is also important to note that comparisons of WTP across treatments should be made with caution because information treatments can affect both the WTP of an individual respondent for their preferred option, but also the proportion of respondents who prefer that option. An information treatment that strengthens preference for an option could therefore either increase mean WTP for that option (because it increases each individual's WTP for the option) or decrease mean WTP for the option (because it induces new individuals to prefer that option who would not otherwise state a preference, and who likely have low WTP for the option). For this reason, we believe that evidence for the effects of historical information on preferences as inferred from the choice model in Section 4.2 is likely to be more informative than effects on mean WTP.

\section{Discussion}

The literature discussed in Section 2 suggests that preferences for landscape should depend both on what is being valued and who is valuing that landscape. The decision to use as experimental treatments the provision of information on (i) how writers in the past have portrayed the Lake District, and (ii) on the extent and nature of past woodland in the Trossachs can be argued to be consistent with the theoretical idea of landscapes as reflections of cultural identity, since the former relates to past perceptions of the landscape and the latter relates to past use of the landscape. However, these past perceptions are usually deemed to be non-specific and undifferentiated. Here we have

\footnotetext{
${ }^{3}$ Results are available from the corresponding author on request.
} 
used specific information from more than one 'past', evidence that most respondents are unlikely to have come across previously. We found that presenting respondents with information relating to differences in past woodland cover relative to the present made them much less likely to prefer the status quo, that made them more likely to prefer a change. This effect was also noted, although less strongly, when people in the Lakes were presented with differing past literary impressions of the landscape.

Moreover, the ideas of "wildness", special-ness" and a worked-in landscape are all aspects of the individually-varying, culturally-influenced perception of landscape that is suggested by the landscape perception and environmental psychology literatures (eg Cheng et al, 2003). Empirically, these were represented here by the variables WORK, WILD and SPECIAL. People with higher SPECIAL scores (ie who felt the Lake District was more special) had a lower probability of choosing the status quo, and a higher probability of choosing the planting option. This is in direct contrast to the Trossachs results, where people who give the area a higher score for SPECIAL are more likely to choose the status quo, and less likely to choose planting or felling. In both areas, this variable has a strongly-significant effect on preferred landscape option. It also indicates that those engaged in landscape management should be aware that public perceptions of 'specialness' associated with a particular landscape do not automatically mean that that landscape should be kept exactly as it is. There may, in fact, be a desire to 'improve' it, the particular attributes of which need to be carefully deduced and which are no doubt culturally and temporally inspired. In contrast, neither WILD nor WORKED was significant in the Trossachs, although WORKED was strongly significant for the Lake 
District. People with higher scores for WORK - that is, those who felt that people had “..always...lived and worked in the Lake District” - showed a lower probability of choosing the status quo, a lower probability of choosing felling, and higher probability of choosing planting. Again, this supports the findings of the SPECIAL category and indicates that this increased preference for planting seems therefore to be related to a view that the Lake District landscape is a working one, rather than a museum.

As Stedman states..” previous behaviour or experiences in the landscape may create lenses through which humans attribute meanings to landscape change “ (p.674): this implies we might have expected to find differences in preferences for future landscape change between visitors and residents. We do indeed find differences between visitors and residents for the Trossachs, since the variable "Resident" is strongly significant in the choice model shown in Table 2. Interestingly, this pattern is not repeated in the Lake District, as Resident is not statistically significant. This may indicate that the Lake District has a more defined and widely-disseminated cultural landscape identity than the Trossachs. Moreover, we did not find any significant relationship between how often one visited either national park, or how long one had lived there, and one's preferences for landscape alternatives, suggesting that the immediate, current impression of each landscape is strong enough to impact on the minds of the respondents, no matter how often they had seen it.

One interesting difference between the two national parks is in terms of peoples' wishes to keep things "as they are”. For the Lakes, a large number of preference votes were for 
the status quo (212 out of 502 responses), while the status quo was a much less popular option in the Trossachs (97 out of 504 responses). This makes sense, given the more dynamic nature of recent land-use change in the Trossachs. One could also argue that the Trossachs is less of an icon of "Scottish-ness" than the Lakes is of "English-ness", which would again suggest a reason as to why the status quo is less preferred in the Trossachs. However, it should be noted that most respondents in the Lake District (290) still preferred to see change, which does not endorse the view that this landscape should, as is often currently the case, be regarded as a 'living museum', described by Whyte (2002) as 'Wordsworth's Lakes with car parks and toilets'.:

One weakness of the results presented here is that we do not know how our respondents relate to the landscape or view potential landscape change, whether it is purely or mainly aesthetic, or mainly in terms of its potential usefulness to them (eg for recreation). Moreover, the location of new planting/ felling within each national park might make a difference to preferences for landscape change, but we did not test for this. In the design used here, planting or felling is represented as taking place throughout the park rather than in specific locations. We are also unable to compare whether text or maps is a more effective means of conveying information on environmental pasts to people, since only one treatment was used in each park. It is also possible that the differences in responses related to the two maps (1750 and 1890, see above) shown to respondents of the Trossachs resulted from greater difficulties in interpreting the former compared to the latter. All these weaknesses suggest avenues for future research. 


\section{$\underline{\text { 6. Conclusions }}$}

What we know or believe about the past is increasingly being recognised as an important aspect of environmental management as it impacts on landscape - how it is perceived, how it is compared with alternatives, and how it is valued. In this paper, we present the results from an investigation of the effects of "new” information about past landscapes on peoples’ preferences for future changes to that landscape. This information related both to how land cover has changed over time, portrayed using historical maps and accompanying contemporary descriptions of land cover, and about how perceptions of landscapes in popular culture have varied, related using readings from two popular travel writers of the $18^{\text {th }}$ century.

The main results that emerge for two "iconic" UK landscapes are that either knowing that a landscape was different in the past or knowing that perceptions of it have changed over time seems to reduce preferences for keeping the landscape as it is today, and to increase preferences for changing this landscape in the future, in this case by planting more woodland. In other words, becoming aware of landscape as a dynamic concept whose physical structure and perception varies over time decreases the demand for the status quo and increases interest in 'improving' it, as we might interpret a willingness to see the planting of native broadleaves, an aspect of the landscape that has been seen, among conservationists, the wider public and forest practitioners, as increasingly desirable over the last few decades. Nevertheless, there is an interesting disparity between the two national parks in terms of the distribution of preferences for keeping the current 
landscape over possible alternatives which, at first glance, could be interpreted as reflecting a more deep-rooted sense that the Lake District should remain as Wordsworth described it Statistically the effects of information about the past are stronger in the Trossachs (where there is a lower current preference for the status quo, and where information relates to actual land cover in the past) than in the Lakes (where there is a stronger preference for the status quo, and information relates to past impressions of the landscape in popular literature). Nevertheless, we must emphasise that, overall, preferences in both cases are for change.

We also find that attitudes to landscape matter in terms of preferences for change: how "special" the landscape is perceived to be makes people more likely to choose the status quo in the Trossachs, but less likely to choose the status quo in the Lake District. How long people felt that humans had lived and worked in the landscape also had an impact on preferences in the Lakes, but not in the Trossachs. This finding in fact contradicts any notion that the driver behind the greater propensity of respondents in the Lake District to desire the status quo is a sense that it is an icon of past cultural value. Since this cuts across the current perceived wisdom of the Lake District as an untouchable cultural asset (Whyte, 2002), future work should seek to ascertain why this should be so.

Land managers and all those with an interest in the protection of natural environments might thus wish to consider both how landscapes have actually changed over time - for example, in terms of the desire to return a national park to some "traditional" means of land management - but also to consider how peoples' perceptions of the living history of 
a landscape helps determine what they wish to see happening to this landscape in the

future. Knowledge of the past seems to have an important and previously-undetected effect on preferences for the future of some of our most treasured landscapes. 


\section{$\underline{\text { References }}$}

Andrews, M. (1989) The Search for the Picturesque. Aldershot, Gower Publishing.

Bateman, I., Carson, R., Day, B., Hanemann, M., Hanley, N., Hett, T., Jones-Lee, M.,

Loomes, G., Mourato, S., Ozdemiroglu, E., Pearce, D., Sugden, R. and Swanson, J. (2002): Economic Valuation with Stated Preference Techniques, A Manual. Edward Elgar, Cheltenhan, UK / Northampton, Ma, USA.

Bullen, J. (1999) Assessing Public Perception of Landscape in Wales: a LANDMAP approach, in: M.B. Usher (Ed) Landscape Character: Perspectives on Management and Change (Edinburgh, The Stationary Office).

Cheng A.C., Kruger L. and Daniels S. (2003) "Place as an integrating concept in natural resource politics” Society and Natural Resources, 16: 87-104.

Council of Europe (2000) The European Landscape Convention - Firenze, 20.X.2000 (ETS No. 176). Council of Europe. Strasbourg.

Daniel, T. C. (2001) Whither scenic beauty? Visual landscape quality assessment in the 21st century, Landscape and Urban Planning, 54 (1-4), pp. 267-281.

Dramstad, W. E., et al. (2001), Integrating landscape-based values - Norwegian monitoring of agricultural landscapes, Landscape and Urban Planning, 57, 257-268. 
Fischer A (2003) Decision behaviour and information processing in contingent valuation surveys. PhD thesis, Gottingen University. Berlin: www.dissertation.de.

Garrod, G.D., Willis, K.G., (1995) "Valuing the Benefits of South Downs Environmentally Sensitive Area”, Journal of Agricultural Economics, 46(2):160-173

Gomez-Limon, J., and J. V. D. Fernandez (1999), “Changes in use and landscape preferences on the agricultural-livestock landscapes of the central Iberian Peninsula (Madrid, Spain)” Landscape and Urban Planning, 44, 165-175.

Greene W (1993) Econometric Analysis, $2^{\text {nd }}$ edition. New York : MacMillan Publishing.

Greider T. and L. Garkovitch (1994) "Landscapes: the social construction of nature and the environment” Rural Sociology, 59 (1), 1-24.

Habron, D. (1998) Visual perception of wild land in Scotland, Landscape and Urban Planning, 42 (1), pp. 45-56.

Hanley, N., R.E.Wright and W.Adamowicz (1998) “Using choice experiments to value the environment: design issues, current experience and future prospects”. Environmental and Resource Economics, 11 (3-4), 413-428. 
Hynes S., Hanley N. and Scarpa R. (2008) "Effects on welfare measures of alternative means of accounting for preference heterogeneity” American Journal of Agricultural Economics, Published article online: doi: 10.1111/j.1467-8276.2008.01148.x

Kaltenborn, B. P., and T. Bjerke (2002) “Associations between environmental value orientations and landscape preferences” Landscape and Urban Planning, 59, 1-11.

Kristrom B. (1997). “Spike models in Contingent Valuation”. American Journal of Agricultural Economics 79:1013-1023.

Lake District National Park Authority (LDNPA) (2003) The Lake District National Park in Figures. http://www.lake-district.gov.uk/lake . Accessed May 1, 2005.

Lake District National Park Authority (LDNPA, 1995) Habitats of the Lake District. http://www.lake-district.gov.uk/lake_district_docs95/factsheets_habitat.pdf. Accessed April 29, 2008.

Loch Lomond and the Trossachs National Park Authority (LLTNPA) (2005) State of the Park Report. http://www.lochlomond-trossachs.org/park/deault.asp?p=109. Accessed May 1, 2005.

Loch Lomond and the Trossachs National Park Authority (LLTNPA) (2006) “An evaluation of the special qualities of Loch Lomond and the Trossachs, Appenidix 
Submitted to Scottish Ministers, 2006”. http://www.lochlomondtrossachs.org/upload/file/parkplan2/Ch7_SQ_low.pdf. Accessed April 28, 2008.

Munro A and Hanley N (1999) “Information, uncertainty and contingent valuation” in Bateman I and Willis K (eds.) Valuing Environmental Preferences. Oxford: Oxford University Press.

Ready R, Navrud S and Dubourg WR (2001) “How do respondents with uncertain Willingness to Pay answer contingent valuation questions?” Land Economics, 77 (3), 315-326.

Ribe, R. G. (2002) "Is scenic beauty a proxy for acceptable management? The influence of environmental attitudes on landscape perceptions” Environment and Behavior, 34, 757-780.

Sheail J (1976) Nature in Trust The history of nature conservation in Britain. Glasgow: Blackie.

Stedman, R. (2003) "Is it really just a social construction? The contribution of physical environment to Sense of Place” Society and Natural Resources, 16: 671-685. 
Van den Berg A.E., Vlek C., Coeterier J. (1998) “Group differences in the aesthetic valuation of nature development plans: a multi-level approach” Journal of Environmental Psychology, 18, 141-157.

Whyte I (2002) “Whose Lake District? Contested landscapes and changing sense of place.” North West Geography, 2 (2), 1-11.

Zube, E. H., Pitt, D. G. \& Evans, G. W. (1983) A life-span developmental study of landscape assessment, Journal of Environmental Psychology, 3, pp. 115-128. 
Figure 1. Preference Scores for future woodland options

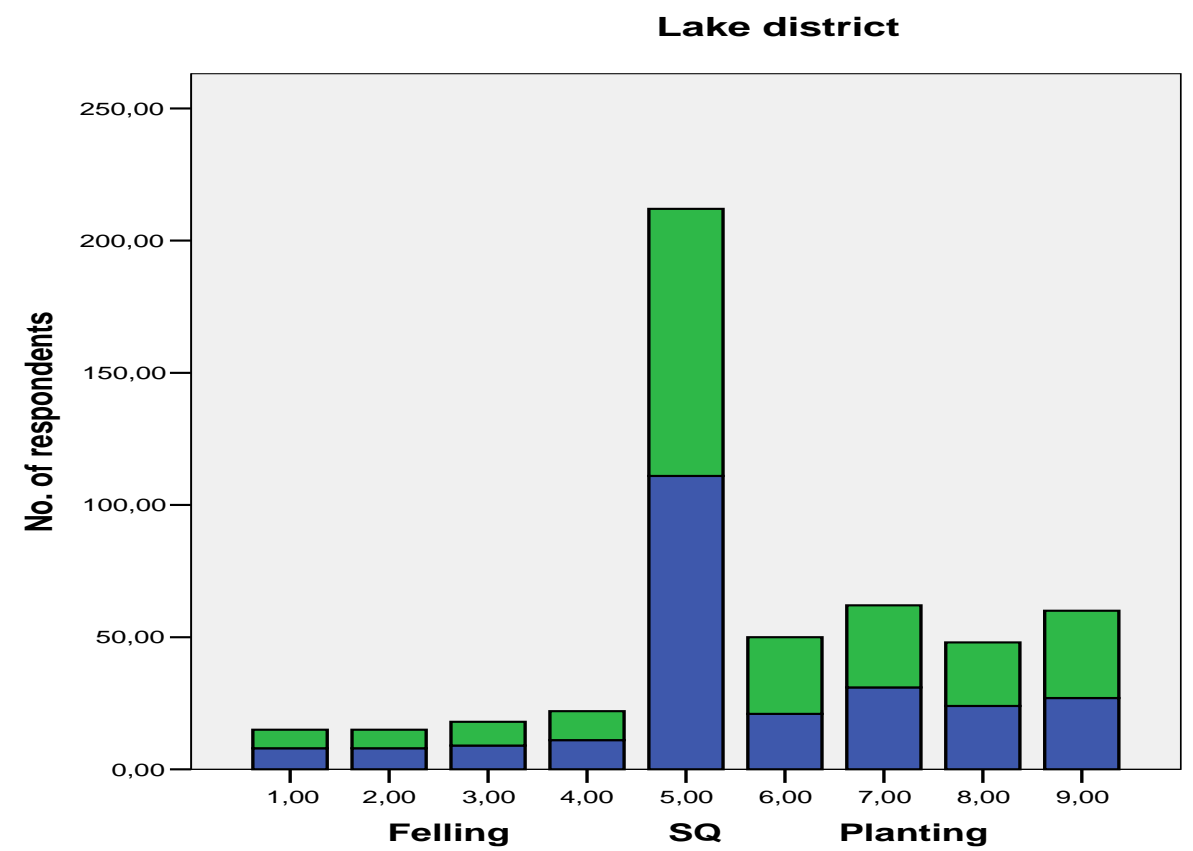

$\square$ Residents

$\square$ Visitors

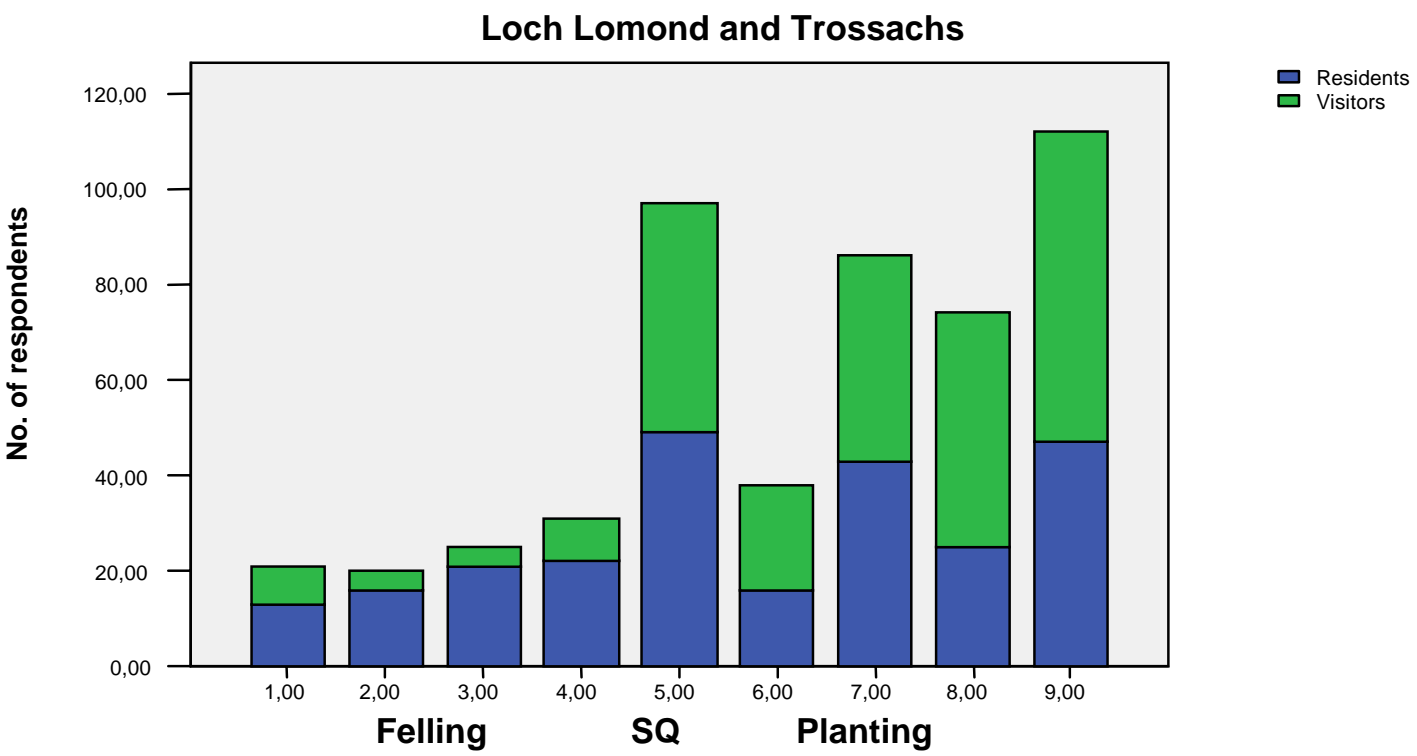


Table 1 .

Comparison of Visitor and Resident data in terms of significance of differences.

\begin{tabular}{|c|c|c|}
\hline & Lake District & Trossachs \\
\hline $\begin{array}{l}\text { Do you think the Lake } \\
\text { District /Trossachs is } \\
\text { special? }\end{array}$ & Significant $^{*}$ & Significant $^{* *}$ \\
\hline $\begin{array}{l}\text { How wild do you feel the } \\
\text { landscape is? }\end{array}$ & Significant $^{*}$ & Not significant \\
\hline Gender & Not significant & Significant $^{* * *}$ \\
\hline Age & Not significant & Significant $^{* * *}$ \\
\hline Income & Not significant & Not significant \\
\hline Education level & Significant $^{* *}$ & Not significant \\
\hline $\begin{array}{l}\text { Are a member of any } \\
\text { environmental/ conservation } \\
\text { trust? }\end{array}$ & Not significant & Not significant \\
\hline
\end{tabular}

Note: Asterisks (e.g., $*, * *, * * *$ ) denote significance at 10\%, $5 \%$ and $1 \%$ level respectively. 
Table 2. Choice model parameter estimates for the Trossachs sample

\begin{tabular}{lcccccc}
\hline & \multicolumn{2}{c}{ Planting } & \multicolumn{2}{c}{ Felling } & \multicolumn{2}{c}{ Significance Tests } \\
\cline { 2 - 7 } Variable & $\begin{array}{c}\text { Parameter } \\
\text { Estimate }\end{array}$ & $\begin{array}{c}\text { Standard } \\
\text { Error }\end{array}$ & $\begin{array}{c}\text { Parameter } \\
\text { Estimate }\end{array}$ & $\begin{array}{c}\text { Standard } \\
\text { Error }\end{array}$ & $\begin{array}{c}\text { sign. } \\
\text { (d.f.) }\end{array}$ & level \\
\hline Intercept & 3.112 & 1.100 & 3.219 & 1.278 & & \\
1750 map & 0.463 & 0.312 & -0.188 & 0.404 & & \\
1890 map & 0.882 & 0.354 & 0.767 & 0.410 & $13.66(6)$ & $5 \%$ \\
Both Maps & 0.333 & 0.325 & -0.408 & 0.431 & & \\
Resident & -0.402 & 0.243 & 1.0265 & 0.321 & $31.94(2)$ & $1 \%$ \\
SPECIAL & -0.521 & 0.215 & -0.627 & 0.248 & $8.03(2)$ & $1 \%$ \\
WILD & -0.115 & 0.129 & -0.284 & 0.163 & $3.10(2)$ & n.s. \\
WORK & 0.161 & 0.116 & -0.018 & 0.146 & $3.24(2)$ & n.s. \\
\hline
\end{tabular}


Table 3. Probability of Preferences, Trossachs sample

\begin{tabular}{lccc} 
Population & \multicolumn{3}{c}{ landscape change } \\
& Felling & SQ \\
No Map & Planting \\
Residents & 0.353 & 0.210 & 0.437 \\
Visitors & 0.128 & 0.213 & 0.660 \\
& & & \\
Residents & 0.244 & 0.176 & 0.580 \\
Visitors & 0.077 & 0.156 & 0.767 \\
& & & \\
Residents & 0.375 & 0.104 & 0.521 \\
Visitors & 0.132 & 0.102 & 0.766 \\
& & & \\
Residents & & Both Maps & 0.578 \\
Visitors & 0.222 & 0.200 & 0.756
\end{tabular}

Note: $\mathrm{SQ}=$ status quo 
Table 4. Choice model parameter estimates for the Lake District sample

\begin{tabular}{lcccccc}
\hline & \multicolumn{2}{c}{ Planting } & \multicolumn{2}{c}{ Felling } & \multicolumn{2}{c}{ Significance Tests } \\
\cline { 2 - 7 } Variable & $\begin{array}{c}\text { Parameter } \\
\text { Estimate }\end{array}$ & $\begin{array}{c}\text { Standard } \\
\text { Error }\end{array}$ & $\begin{array}{c}\text { Parameter } \\
\text { Estimate }\end{array}$ & $\begin{array}{c}\text { Standard } \\
\text { Error }\end{array}$ & $\begin{array}{c}\text { sign. } \\
\text { level }\end{array}$ \\
\hline Intercept & -3.458 & 0.554 & -1.480 & 0.656 & & \\
Positive Reading & 0.239 & 0.290 & -0.024 & 0.377 & & \\
Negative Reading & 0.478 & 0.294 & -0.083 & 0.387 & $5.05(6)$ & n.s. \\
Both Readings & 0.462 & 0.290 & -0.204 & 0.402 & & \\
Resident & -0.178 & 0.207 & 0.058 & 0.284 & $1.03(2)$ & n.s. \\
SPECIAL & 0.347 & 0.117 & 0.319 & 0.157 & $10.71(2)$ & $1 \%$ \\
WILD & 0.191 & 0.105 & -0.077 & 0.142 & $4.84(2)$ & $10 \%$ \\
WORK & 0.318 & 0.096 & -0.159 & 0.123 & $17.76(2)$ & $1 \%$. \\
\hline
\end{tabular}


Table 5. Probability of Preferences, Lake District sample

\begin{tabular}{|c|c|c|c|}
\hline \multirow[t]{2}{*}{ Population } & \multirow{2}{*}{\multicolumn{2}{|c|}{$\begin{array}{l}\text { Felling } \\
\text { No Reading }\end{array}$}} & \multirow[t]{2}{*}{ Planting } \\
\hline & & & \\
\hline residents & 0.153 & 0.432 & 0.414 \\
\hline visitors & 0.135 & 0.403 & 0.462 \\
\hline \multicolumn{4}{|c|}{ Positive Reading } \\
\hline residents & 0.135 & 0.390 & 0.475 \\
\hline visitors & 0.117 & 0.359 & 0.523 \\
\hline \multicolumn{4}{|c|}{ Negative Reading } \\
\hline residents & 0.113 & 0.348 & 0.538 \\
\hline visitors & 0.098 & 0.317 & 0.586 \\
\hline \multicolumn{4}{|c|}{ Both Readings } \\
\hline residents & 0.103 & 0.356 & 0.541 \\
\hline visitors & 0.088 & 0.324 & 0.588 \\
\hline
\end{tabular}

Note: $\mathrm{SQ}=$ status quo 
Table 6 Willingness to Pay for felling and planning (no distinction between information treatment), in $£$ per person

(a) All respondents

\begin{tabular}{|l|l|l|l|}
\hline & $\begin{array}{l}\text { \% preferring status } \\
\text { quo }\end{array}$ & Mean WTP, & $\begin{array}{l}\text { 95\% confidence } \\
\text { interval }\end{array}$ \\
\hline $\begin{array}{l}\text { Trossachs, WTP for } \\
\text { felling }\end{array}$ & $63 \%$ & 1.23 & $0.79-1.77$ \\
\hline $\begin{array}{l}\text { Trossachs, WTP for } \\
\text { planting }\end{array}$ & $24 \%$ & 2.48 & $2.21-2.75$ \\
\hline $\begin{array}{l}\text { Lakes, WTP for } \\
\text { felling }\end{array}$ & $80 \%$ & 0.45 & $0.28-0.61$ \\
\hline $\begin{array}{l}\text { Lakes, WTP for } \\
\text { planting }\end{array}$ & $53 \%$ & 1.34 & $1.11-1.57$ \\
\hline
\end{tabular}

(b) Residents Only

\begin{tabular}{|l|l|l|l|}
\hline & $\begin{array}{l}\text { \% preferring status } \\
\text { quo }\end{array}$ & Mean WTP & $\begin{array}{l}\text { 95\% confidence } \\
\text { interval }\end{array}$ \\
\hline $\begin{array}{l}\text { Trossachs, WTP for } \\
\text { felling }\end{array}$ & 62 & 1.38 & $0.78-1.98$ \\
\hline $\begin{array}{l}\text { Trossachs, WTP for } \\
\text { planting }\end{array}$ & 41 & 2.07 & $1.57-2.57$ \\
\hline $\begin{array}{l}\text { Lakes, WTP for } \\
\text { felling }\end{array}$ & 82 & 0.34 & $0.15-0.53$ \\
\hline $\begin{array}{l}\text { Lakes, WTP for } \\
\text { planting }\end{array}$ & 58 & 0.84 & $0.63-1.05$ \\
\hline
\end{tabular}

(c) Visitors Only

\begin{tabular}{|l|l|l|l|}
\hline & $\begin{array}{l}\text { \% preferring status } \\
\text { quo }\end{array}$ & Mean WTP & $\begin{array}{l}\text { 95\% confidence } \\
\text { interval }\end{array}$ \\
\hline $\begin{array}{l}\text { Trossachs, WTP for } \\
\text { felling }\end{array}$ & 65 & 1.05 & $0.23-1.87$ \\
\hline $\begin{array}{l}\text { Trossachs, WTP for } \\
\text { planting }\end{array}$ & 15 & 2.76 & $2.43-3.09$ \\
\hline $\begin{array}{l}\text { Lakes, WTP for } \\
\text { felling }\end{array}$ & 78 & 0.56 & $0.28-0.84$ \\
\hline $\begin{array}{l}\text { Lakes, WTP for } \\
\text { planting }\end{array}$ & 46 & 1.80 & $1.39-2.21$ \\
\hline
\end{tabular}

